Island Studies Journal, Vol. 4, No. 1, 2009, pp. 99-100

\title{
China and USA in the Pacific and the Caribbean: Whose Incursion, Whose Territory? A Brief Rejoinder to McElroy and Bai
}

\author{
Ron Crocombe \\ Rarotonga \\ Cook Islands \\ ronc@,oyster.net.ck
}

The title of the article in Island Studies Journal by McElroy and Bai (2008) illustrates an inherent bias. It says that it is about China's "incursion" into the Caribbean and Pacific. The Oxford on-line dictionary's main definition of incursion is "an invasion or attack, especially a sudden or brief one"; and my Collins dictionary gives its main definition as: "a sudden invasion, attack or raid." Since there has never been any invasion, attack or raid (and therefore no incursion) by China into the Pacific or the Caribbean, why do the authors imply that there is?

In contrast, there have been plenty of "invasions, attacks and raids" by the USA in the Pacific Islands and the Caribbean during the past 150 years.

Until recently, competition between individual Western nations and individual Asian nations in the Pacific and Caribbean was overshadowed by the much greater competition between individual Western nations themselves - even to the extent of war. In the Pacific, USA took Guam from Spain by military force in 1898, and in 1944 USA took all Micronesian territories north of the equator by military force. The Australian, New Zealand and Japanese navies conquered Germany's Pacific colonies in 1914; and USA sent warships and took over 60 Pacific Islands long before its navy forced the surrender of Hawai'i to USA. The only incursions into the Pacific Islands and the Caribbean have been by Western powers and Japan.

Competition between Asian and Western interests in the Pacific has been apparent for 100 years, starting with US competition with Japan for influence in Micronesia from the late $1800 \mathrm{~s}$. Western/Asian competition increased markedly during the past 40 years in the Pacific Islands, and to a lesser extent in the Caribbean. That competition is for influence in all fields between Western powers (especially USA, Australia, New Zealand and Europe) and Asian states (especially Japan, China, Korea, Taiwan, Indonesia and India).

The essay begins by describing China's (which includes PRC/China and ROC/ Taiwan) activities in the Pacific as a "juggernaut" (p. 226). My Collins dictionary defines this as "any terrible force, especially one that demands complete selfsacrifice" and notes that it derives from Hindi in which devotees of Krishna threw themselves under the wagon carrying his effigy. The Oxford Internet dictionary describes it as a large truck, with the same Hindi origin. A rather bizarre analogy.

In fact, Western nations still enjoy much greater influence in the Pacific Islands and the Caribbean - whether in exports, aid, military investment, religious, linguistic, information, cultural or other influences than China or Asia generally, though that is in the process of changing. But those larger influences from the West are never described by the authors with such negative terminology. USA is currently spending an extra US\$15 billion to expand its already huge military establishment on the tiny 


\section{R. Crocombe}

island of Guam, is also expanding on the Mariana Islands, and tests all its intercontinental ballistic missiles in the Marshall Islands. All of that is aimed at China more than at any other country. And US naval vessels loaded with military hardware and nearly 1,000 military personnel each as well as tanks and helicopters patrol the coasts of China, while US spy aircraft and satellites fly above its coasts, photographing every detail and eavesdropping on its communications. If China did the same to the USA, there would be an outcry about aggression and provocation.

Aid from China and Taiwan is described as "largesse" and "cheque-book diplomacy" which is "lavished" on the Islands to "buy" or "rent" their "friendship" (e.g. pp. 226, 230, 239), but larger amounts of aid from Western nations, using more sophisticated "cheque-book diplomacy" (e.g. pp. 233, 237) and involving every bit as much donor self-interest and leverage are not described in negative terms. Inter-governmental aid from all countries is determined more by the interests of the donor government than by the needs of recipient countries.

China and Taiwan fund "junkets" (p. 239), give cars to political leaders, pay for government buildings, and train and equip military forces in the Islands. They do, but in doing so they are following the model long established by the Western powers in the region, which have done all that on a larger scale.

Likewise, we are told (via a quote) that China uses its "economic might" (p. 227) to further political objectives. True; and which major power does not? Western nations tie their aid to their ideology, values and interests more than China. As Emanuel Mori (President, Federated States of Micronesia) observed recently, and any Pacific Islands Ministry of Foreign Affairs will confirm, the Chinese simply ask: "What do you need?"; whereas Western states apply many more conditions and use aid for longterm leverage, even more than China.

The article tells us that: "PRC has also constructed large fish processing plants in the Cook Islands" (p. 235). This is untrue. It has constructed none: large, small or medium.

The PRC has "an aggressive political presence in the Pacific" (p. 235). It does, though not as aggressive as that of Australia in the South Pacific or USA in the North Pacific Islands - but the article does not mention that.

We are told: “...some commentators see in Beijing's Pacific strategy a long-run thrust for hegemony" (p. 235). I expect that is true. It has certainly been true of the USA for over 50 years and is vigorously maintained in the North Pacific Islands. In the South Pacific, the USA now delegates the lead role in protecting its interests to Australia.

The authors have done us a service by bringing together some data on China's relationship with the insular Caribbean and the Pacific; but one hopes that their further studies on the topic will aim for a deeper objectivity.

\section{References}

McElroy, J. L. and Bai, W. (2008) 'The Political Economy of China's Incursion into the Caribbean and Pacific', Island Studies Journal, Vol. 3, No. 2, pp. 225-246. 